\title{
Cele rehabilitacji słuchowej przeznaczonej dla dzieci i dorosłych korzystających z implantu ślimakowego
}

\section{The objectives of hearing rehabilitation dedicated to children and adult cochlear implant users}

\author{
Joanna Katarzyna Rostkowska, Agnieszka Pankowska \\ Instytut Fizjologii i Patologii Słuchu, Światowe Centrum Słuchu, Klinika Rehabilitacji, Warszawa/Kajetany \\ Adres autora: Joanna Rostkowska, Światowe Centrum Słuchu, Klinika Rehabilitacji, ul. Mokra 17, Kajetany, \\ 05-830 Nadarzyn, e-mail: j.rostkowska@ifps.org.pl
}

\begin{abstract}
Streszczenie
W artykule opisano cele rehabilitacji słuchowej prowadzonej z wykorzystaniem materiału językowego (głoski, sylaby, wyrazy, zdania, frazy) z osobami, które korzystają z implantów ślimakowych. Zaproponowano podział na grupy w zależności od etapu opanowania kompetencji lingwistycznej. Tekst jest próbą określenia założeń i wskazówek potrzebnych do prowadzenia efektywnej, wykorzystującej materiał językowy rehabilitacji słuchowej osób korzystających z implantów ślimakowych.
\end{abstract}

W artykule pominięto zagadnienie ćwiczeń słuchowych wykorzystujących dźwięki otoczenia.

Słowa kluczowe: niedosłuch • trening słuchowy • implant ślimakowy

\begin{abstract}
This paper describes the objectives of hearing rehabilitation conducted using language material (phones, syllables, words, sentences, phrases) with cochlear implant users. Authors propose classification in groups according to the level of linguistic skills (language, communication, culture). This paper is an attempt to define the principles and guidelines for hearing rehabilitation of people with hearing impairments with the application of language material.
\end{abstract}

In relation to the topic of this article concerning hearing rehabilitation conducted using language material, exercises with environmental sounds have been omitted in this text.

Key words: hearing loss • auditory training • cochlear implant

\section{Wstęp}

Rehabilitacja słuchowa [1] prowadzona z wykorzystaniem materiału językowego to szereg zaplanowanych działań terapeutycznych skierowanych do osób z niedosłuchem. Cele stawiane w rehabilitacji słuchowej zależą od wielu czynników. Nadrzędnym czynnikiem jest moment wystąpienia niedosłuchu, który z kolei wpływa na stopień opanowania kompetencji lingwistycznej [2]. W wypadku niedosłyszących dzieci celem rehabilitacji słuchowej jest kształtowanie (nabywanie i doskonalenie) kompetencji lingwistycznej z wykorzystaniem percepcji słuchowej (w komfortowych oraz w niesprzyjających warunkach akustycznych). W wypadku osób ogłuchłych po opanowaniu kompetencji lingwistycznej (postlingwalnie) [3] rehabilitacja słuchowa prowadzi do odzyskania możliwości słuchowego odbioru mowy w różnych warunkach akustycznych.
Nabywanie kompetencji lingwistycznej z wykorzystaniem percepcji słuchowej

W związku z przeprowadzaniem diagnostyki audiologicznej u coraz młodszych dzieci i stosowaniem u nich implantów ślimakowych już po 6 miesiącu życia [4], kompetencja lingwistyczna dzieci niedosłyszących korzystających $\mathrm{z}$ implantu ślimakowego może kształtować się w taki sam sposób jak u dzieci prawidłowo słyszących. Potwierdzają to liczne badania [5-15]. Nabywanie kompetencji lingwistycznej odbywa się poprzez wielokrotne słuchanie wypowiedzeń osób dorosłych oraz dzięki naturalnej potrzebie dziecka do komunikowania swoich myśli i bycia zrozumianym przez otoczenie. Dzieci spontanicznie uczą się słownika i gramatyki języka (kompetencja językowa), posługiwania się językiem w sposób skuteczny i dostosowany do sytuacji (kompetencja komunikacyjna) oraz posługiwania 
się środkami symbolicznymi i zróżnicowanymi znaczeniami (kompetencja kulturowa) [2].

Dlatego też rehabilitacja słuchowa prowadzona u małych dzieci korzystających z implantu ślimakowego ma na celu wykształcenie kompetencji językowej, komunikacyjnej i kulturowej. Zastosowana w ich wypadku rehabilitacja słuchowa zawiera się w szeroko pojętym wychowaniu słuchowym [16-18]. Tym terminem określa się działania prowadzące do zebrania przez dzieci niedosłyszące doświadczeń akustycznych umożliwiających rozwój języka i mowy (realizacji języka). Korzon dowodzi, że wychowanie słuchowe musi być częścią składową wychowania i kształcenia ogólnego [19]. Prawidłowo prowadzone wychowanie słuchowe jest fundamentem ogólnego rozwoju [20]. Łatwo zgodzić się z tymi stwierdzeniami, jeśli weźmie się pod uwagę, że język jest środkiem, za pomocą którego zachodzi myślenie [21], a funkcjonowanie odbywa się w określonej rzeczywistości kulturowej. Wychowanie słuchowe powinno być realizowane dwiema drogami: w sposób niewymuszony i we wszystkich codziennych sytuacjach życiowych (stosowanie zasad metody audytywno-werbalnej [22]) oraz poprzez wykorzystanie odpowiednio dobranych, progresywnie uporządkowanych ćwiczeń słuchowych, takich jak: percepcja, dyskryminacja oraz identyfikacja dźwięku i rozumienie mowy w sytuacji wymiany informacji [23].

Ćwiczenia percepcji dźwięku polegają na nauce wysłuchiwania i reagowania na różne dźwięki, ale przede wszystkim na dźwięki mowy. Wymagają aranżowania wielu sytuacji dźwiękowych, zwracania uwagi na dźwięki i ich konsekwencje oraz towarzyszące im emocje. Podstawowym ćwiczeniem jest nauka reagowania na imię (wołanie), która może być wprowadzeniem do rozpoczęcia nauki warunkowanej odpowiedzi na bodziec dźwiękowy (przygotowanie do badania audiometrycznego).

Ćwiczenia dyskryminacji dźwięków polegają na umiejętności postrzegania różnic i podobieństw między dźwiękami, a w szczególności między dźwiękami mowy. Podobieństwa i różnice mogą dotyczyć tempa, natężenia, czasu trwania, częstotliwości (barwy dźwięku), dynamiki. Zadaniem dziecka jest porównanie i ocena, czy usłyszane głoski, onomatopeje, wyrazy, frazy lub zdania są takie same czy też różne. Ćwiczenia rozpoczynają się od dyskryminacji zdarzeń akustycznych ujętych w zbiorze zamkniętym, poprzez zbiór półotwarty (ze wskazówką tematyczną lub sytuacyjną) aż po zbiór otwarty (bez jakiejkolwiek podpowiedzi) [24]. Na tym etapie ważne jest słuchowe dostrzeżenie różnicy między dźwiękami mowy, a nie ich powtarzanie.

Nauka identyfikacji dźwięków polega na powiązaniu usłyszanego sygnału ze znaczeniem. Ćwiczenia tego etapu dotyczą głosek (samogłoski, spółgłoski), pojedynczych wyrazów (rzeczowników, czasowników, przymiotników, przysłówków, wyrażeń przyimkowych) oraz fraz i zdań. Zadaniem dziecka jest wykonanie prostego polecenia, polegającego na powtórzeniu, wskazaniu lub podaniu obrazka, przedmiotu, który odnosi się do słyszanego wypowiedzenia. Najprostsze ćwiczenie polega na identyfikacji wyrazów znajdujących się przed dzieckiem na stoliku, na ekranie komputera, na dywanie. Nieco trudniejsze ćwiczenie polega na rozpoznawaniu fraz i zdań, a najtrudniejsze ćwiczenie - na identyfikacji wyrazów, zdań, fraz wymawianych bez podpowiedzi obrazka czy kontekstu.

Rozumienie mowy w sytuacji wymiany informacji jest zadaniem wymagającym największych umiejętności w zakresie kompetencji lingwistycznej i percepcji słuchowej mowy. Jest to umiejętność rozpoznawania znaczenia mowy poprzez wykonywanie poleceń, odpowiadanie na pytania, uczestniczenie $\mathrm{w}$ dialogu. Takie zadania realizuje się, korzystając $z$ prostych form narracyjnych, bajek, historii przyczynowo-skutkowych. Prawidłowe rozumienie mowy w sytuacji wymiany informacji świadczy o wykształceniu kompetencji lingwistycznej.

Zakres materiału językowego wykorzystywany do ćwiczeń musi być bezwzględnie zależny od stopnia rozwoju kompetencji lingwistycznej oraz od możliwości poznawczych dziecka. Dwulatkowi proponuje się prostą słuchowo-językową zabawę lalką, autem i klockami, a wraz z rozwojem - bardziej rozbudowaną zabawę w sklep, weterynarza, farmę czy gotowanie (należy pamiętać o zamianie ról w zabawie, po to żeby rozwijać nie tylko słownik bierny, lecz także słownik czynny dziecka). Dokonując wyboru materiału językowego, należy kierować się także zasadą użyteczności - ważne jest to, co umożliwi porozumiewanie $\mathrm{w}$ celu zaspokojenia potrzeb charakterystycznych dla wieku. Wraz z progresem w rozwoju poznawczym i lingwistycznym ten obszar będzie zataczał coraz większy krąg (od „Daj!” do „Posłuchaj, co mi się dzisiaj przydarzyło. Jaka jest twoja opinia na ten temat?").

Na etapie nabywania kompetencji lingwistycznej odbywa się również intensywna nauka prawidłowej artykulacji głosek lub korygowanie tych, które artykułowane są nieprawidłowo.

\section{Doskonalenie kompetencji lingwistycznej nabywanej dzięki percepcji słuchowej}

Edukacja początkowa wymaga od dzieci nie tylko odpowiedniego poziomu kompetencji lingwistycznej, lecz także stawia przed nimi wyzwanie dotyczące utrzymania odpowiedniego skupienia uwagi słuchowej w celu pozyskiwania informacji w niesprzyjających warunkach akustycznych. Badania naukowe dotyczące edukacji dzieci z implantami ślimakowymi potwierdzają, iż te wcześnie zaopatrzone w implanty ślimakowe mogą uczyć się razem ze słyszącymi rówieśnikami w szkołach ogólnodostępnych i opanować materiał edukacyjny w stopniu satysfakcjonującym [25] lub nieco odbiegającym od średniej klasowej [26,27].

Głównym celem rehabilitacji słuchowej prowadzonej z wykorzystaniem materiału językowego u dzieci korzystających z implantów ślimakowych po rozpoczęciu nauki w szkole podstawowej jest doskonalenie kompetencji lingwistycznej. Kolejny cel rehabilitacji słuchowej to trenowanie, za pomocą tekstów informacyjnych, popularnonaukowych, literackich, urzędowych, korzystania $z$ tej kompetencji nie tylko w komfortowym środowisku akustycznym, lecz także w hałasie. Do treningu wykorzystać można informacje pochodzące $z$ podręczników, lektury szkolne czytane przez terapeutę lub nagrane i odtwarzane (książki audio). Zadaniem dziecka jest słuchanie, zapamiętanie narracji na takim poziomie, który umożliwi 
Tabela 1. Plan treningu słuchowego dla osób postlingwalnie ogłuchłych korzystających z implantu ślimakowego

Table 1. Plan of auditory training for the postlingually deafened cochlear implant users

\section{A. Detekcja i dyskryminacja}

1. Dyskryminacja na podstawie długości wyrazu

2. Śledzenie krótkiego tekstu zbudowanego ze słów jedno- i dwusylabowych

3. Śledzenie krótkiego tekstu zbudowanego ze słów: jedno- i dwusylabowych, tylko dwusylabowych

4. Dyskryminacja zdań o tym samym trzonie, zakończonych wyrazem różniącym się długością (różna liczba sylab)

5. Dyskryminacja zdań i słów na podstawie barwy głosek (barwa głoski zależy od charakterystycznych dla niej tonów składowych - formantów)

6. Dyskryminacja wzoru zdań i wyrazów

\section{B. Dyskryminacja i identyfikacja}

1. Identyfikacja na podstawie długości wyrazu

2. Identyfikacja zdania na podstawie wysokości głoski

3. Identyfikacja na podstawie długości frazy

4. Identyfikacja zdań na podstawie długości

5. Śledzenie tekstu zbudowanego ze słów: jedno- i dwusylabowych, tylko dwusylabowych

6. Trening korzystania z telefonu

7. Dyskryminacja na podstawie długości samogłoski

8. Dyskryminacja zdań pytających i twierdzących

\section{Identyfikacja i rozpoznawanie}

1. Identyfikacja zdania na podstawie rozmieszczonego akcentu

2. Identyfikacja akcentowanego wyrazu

3. Trening korzystania z telefonu

4. Identyfikacja spondejów

5. Identyfikacja zdań o tej samej długości w zestawie zamkniętym

6. Rozpoznawanie zdań powiązanych ze sobą - temat kluczowy i wskazówki słowne

7. Rozpoznawanie zdań powiązanych ze sobą - wskazówki frazy kluczowej

8. Rozpoznawanie zdań powiązanych ze sobą - wskazówki zdaniowe oparte na kluczu tematycznym

9. Rozpoznawanie zdań powiązanych ze sobą - wskazówki dotyczące zdania kluczowego

\section{Rozpoznawanie i rozumienie}

1. Wypowiedzi dobrze znane

2. Zdania dobrze znane powiązane tematycznie

3. Łatwe opowiadania $z$ interakcją

4. Zdania powiązane tematycznie - wskazówka tematyczna wyrażona przez słowo kluczowe

5. Zdania niepowiązane ze słowami kluczowymi

6. Zdania w zestawie otwartym bez słów kluczowych

7. Praktyka rozmowy telefonicznej - zdania PAL

8. Rozszerzone opowiadanie z interakcją 
udzielanie odpowiedzi na pytania, prowadzenie dialogu lub zadawanie adekwatnych pytań i rozwiązywanie postawionych problemów na poziomie słownikowym. Proponowane ćwiczenia mogą bazować na wiadomościach szkolnych znanych dziecku (ćwiczenia w zbiorze zamkniętym lub półotwartym), mogą także wprowadzać nowy materiał edukacyjny (ćwiczenia w zbiorze półotwartym, otwartym). Istotne jest stosowanie czynnika utrudniającego słuchowy odbiór mowy. Tym czynnikiem może być zwiększenie liczby uczestników zajęć, oddalanie od źródła dźwięku, zmniejszenie natężenia odbieranej narracji, wprowadzenie zakłóceń $\mathrm{w}$ formie specjalnie dobranych szumów o różnym natężeniu i częstotliwości.

Na tym etapie rehabilitacji wciąż odbywa się ewentualne korygowanie artykulacji.

\section{Rehabilitacja słuchowa $\mathrm{w}$ formie treningu słuchowego}

Uczestnikami programu rehabilitacji słuchowej realizowanej w formie treningu słuchowego są osoby postlingwalnie ogłuchłe $[1,24]$. W tym wypadku rehabilitacja słuchowa polega na odnowieniu śladów pamięciowych wzorców słuchowych i połączeniu ich $\mathrm{z}$ wrażeniami słuchowymi docierającymi za pomoca implantu ślimakowego [28]. Celem treningu słuchowego prowadzonego u osób postlingwalnie ogłuchłych zaopatrzonych w implant ślimakowy jest przywrócenie możliwości słuchowego odbioru mowy. Działania realizowane $\mathrm{w}$ ramach treningu słuchowego zostały podzielone na następujące po sobie etapy: detekcja, dyskryminacja, identyfikacja, rozumienie. W tabeli 1 przedstawiono plan treningu słuchowego przeznaczonego dla osób postlingwalnie ogłuchłych, korzystających z implantu ślimakowego [29].

Początkowy etap to nauka detekcji dźwięków mowy. Podstawowe zadanie ćwiczącego to wysłuchanie dźwięku w sytuacji, gdy jest on oczekiwany, i w sytuacji, gdy się go nie spodziewa. Następnie wymaga się od niego oceny, czy dwa usłyszane wyrazy, zdania są takie same czy różne. Jest to już etap dyskryminacji, na którym kształtowana jest sprawność różnicowania mowy, a wskazówkę stanowi czas trwania, wysokość i natężenie (cechy suprasegmentalne). Jednym z ćwiczeń jest także śledzenie (wodzenie palcem po wyrazach) tekstu czytanego przez terapeutę.

Kolejny etap to identyfikacja, czyli wiązanie usłyszanego szeregu dźwięków (wyrazy, zdania, wypowiedzenia) ze znaczeniem. Ćwiczący, wykonując to zadanie, kieruje się cechami segmentalnymi i suprasegmentalnymi. Łatwiejszą wersją ćwiczeń prowadzonych na tym etapie jest identyfikacja haseł znajdujących się w zbiorze zamkniętym, a wersja zaawansowana polega na identyfikowaniu haseł na podstawie zbioru półotwartego. To oznacza, że zastosowany materiał językowy nie jest bezpośrednio prezentowany pacjentowi. Terapeuta dostarcza wskazówek, określając zakres słownictwa poprzez podanie tematu lub słowa kluczowego. Opanowanie tej umiejętności umożliwia rozpoczęcie trenowania rozumienia mowy w sytuacji sprzyjającej akustycznie.

Ćwiczenia w rozumieniu mowy polegają na ujmowaniu słyszanej treści innymi słowami i odpowiadaniu na pytania zadawane do tekstu. Ostatnim etapem rehabilitacji słuchowej prowadzonej $\mathrm{z}$ wykorzystaniem materiału językowego jest nauka rozumienia mowy w naturalnych warunkach akustycznych, które uzyskuje się poprzez oddalenie od źródła dźwięku, dodanie dźwięków zakłócających, zwiększenie liczby rozmówców, wprowadzenie zakłóceń $\mathrm{w}$ formie specjalnie dobranych szumów o różnym natężeniu i częstotliwości. Na wszystkich etapach treningu słuchowego wykorzystywane są sylaby, wyrazy, frazy, pojedyncze zdania i teksty, dopasowane swoją strukturą do określonego ćwiczenia i obejmujące zjawiska fonetyczne właściwe językowi polskiemu [30].

Liczne doniesienia naukowe potwierdzają konieczność prowadzenia treningu słuchowego i osiąganie dzięki niemu wysokich wyników w zakresie słuchowego odbioru mowy [31-39].

Swoistą grupę pacjentów stanowią osoby, które otrzymały implant ślimakowy po 60 roku życia. Wymagają one szczególnego podejścia terapeutycznego, opartego na zasadach geragogiki $[40,41]$. Proponowany im trening słuchowy powinien być skoncentrowany na ćwiczeniach rozumienia zdań ze wskazówką tematyczną (poziom konwersacji). Badania naukowe wykazują, że także ta grupa osób korzystających z implantu słuchowego osiąga wysokie wyniki w testach oceniających możliwości percepcji słuchowej [31-39].

\section{Wnioski}

1. Każdy użytkownik implantu ślimakowego, niezależnie od wieku, powinien zostać poddany odpowiednio dobranej rehabilitacji słuchowej.

2. Ogólne cele rehabilitacji słuchowej stanowią kanwę do konstruowania indywidualnych programów rehabilitacji słuchowej, odpowiadających potrzebom konkretnych osób korzystających z implantu ślimakowego.

3. W wypadku dzieci prelingwalnie ogłuchłych, które zostały zaopatrzone $\mathrm{w}$ implant ślimakowy $\mathrm{w}$ pierwszym roku życia, celem rehabilitacji słuchowej jest opanowanie i doskonalenie kompetencji lingwistycznej na bazie percepcji słuchowej.

4. W wypadku dzieci korzystających $\mathrm{z}$ implantu ślimakowego, które opanowały kompetencję lingwistyczną na poziomie podstawowym, należy zwrócić szczególną uwagę na trenowanie percepcji słuchowej w środowisku trudnym akustycznie.

5. Celem rehabilitacji słuchowej proponowanej osobom postlingwalnie ogłuchłym korzystającym $\mathrm{z}$ implantu ślimakowego jest przywrócenie możliwości słuchowego rozumienia mowy w różnych warunkach akustycznych.

6. Rehabilitacja słuchowa osób zaopatrzonych w implant ślimakowy po 60 roku życia powinna obejmować te etapy treningu słuchowego, które dadzą możliwość rozumienia mowy na poziomie konwersacji (wskazówka tematyczna).

Artykut powstał w zwiazku z realizacja projektu „Zintegrowany system narzędzi do diagnostyki i telerehabilitacji schorzeń narząów zmystów (słuchu, wzroku, mowy, równowagi, smaku, powonienia)" INNOSENSE, wspólfinansowanego przez Narodowe Centrum Badań $i$ Rozwoju w ramach Programu STRATEGMED. 


\section{Piśmiennictwo:}

1. Kosmalowa J, red. Rehabilitacja dzieci i młodzieży z uszkodzonym słuchem. Warszawa: Instytut Fizjologii i Patologii Słuchu; 2001.

2. Rittel T. Podstawy lingwistyki edukacyjnej. Kraków: Wydawnictwo Naukowe WSP-Kompetencje; 1994.

3. Kurkowski ZM. Audiogenne uwarunkowania zaburzeń komunikacji językowej. Lublin: Wydawnictwo UMCS; 2013.

4. Lorens A, Skarżyński H. Technologia implantów ślimakowych. Nowa Audiofonologia, 2012; 1(3): 18-23.

5. Manrique M, Cervera-Paz F, Huarte A, Molina M. Advantages of cochlear implantation in prelingual deaf children before 2 years of age when compared with later implantation. Laryngoscope, 2004; 114: 1462-69.

6. Nicholas J, Geers A. Spoken language benefits of extending cochlear implant candidacy below 12 months of age. Otol Neurotol, 2013; 34: 532-38.

7. Niparko J, Tobey E, Thal D, Eisenberg L, Wang N, Quittner A, Fink N. Spoken language development in children following cochlear implantation. JAMA, 2010; 303: 1498-506.

8. Harrison RV, Panesar J, EI-Hakim H, Abdoek M, Mount RL, Papsin B. The effects of age of cochlear implantation on speech perception in prelingually deaf children. Scan Audio Suppl, 2001; 53, 73-78.

9. Skarżyński H, Góralówna M, Janczewski G, Geremek A. Wybrane problemy w stosowaniu implantów ślimakowych. Otolaryngol Pol, 1993; 47(3): 217.

10. Yoshinaga-Itano C, Sedey AL, Coulter DK, Mehl AL. Language of early- and later-identified children with hearing loss. Pediatrics, 1998; 102(5): 1161-71.

11. Luxford WM, Winter M, Eisenberg L. Evaluation of the 12 to 18-month-old cochlear implant candidate. The $6^{\text {th }}$ International Cochlear Implant Conference; 2002.

12. Dolan-Ash S. Speech perception and language abilities of children implanted under the age of two year. The $6^{\text {th }}$ International Cochlear Implant Conference; 2002.

13. Edwards J, Willis S, Tyszkiewicz E, Henderson L, Ramsden R. Cochlear implants in the under 2's and under 3's. The $6^{\text {th }}$ International Cochlear Implant Conference; 2002.

14. Parisier SC, Chute PM, Popp AL. Cochlear implant results in children under 20 months of age. The $6^{\text {th }}$ International Cochlear Implant Conference; 2002.

15. Kirk KI, Miyamoto RT, Lento CL, Ying E, O’Neill T, Fears B. Effects of age at implantation in young children. Ann Otol Rhinol Laryngol Suppl, 2002; 189: 69-73.

16. Löwe A. Wychowanie słuchowe. Historia - metody - możliwości. Warszawa: Wydawnictwo Naukowe PWN; 1995.

17. Rosier H. Wychowanie słuchowe. Warszawa: Instytut Fizjologii i Patologii Słuchu; 1997.

18. Csanyi Y. Słuchowo-werbalne wychowanie dzieci z uszkodzonym narządem słuchu. Warszawa: Wydawnictwa Szkolne i Pedagogiczne; 1994.

19. Korzon A. Wychowanie słuchowe dzieci z wadą słuchu. Katowice: Infograf.

20. Jann PA. Kommunikative Lautspracherziehung im Elterhaus. Hörgeschädigte Kinder 25. Jahrg; 1988.

21. Jurek A. Rozwój dziecka a metody nauczania czytania i pisania. Gdańsk; 2012.
22. Pankowska A, Barej A, Lutek A, Zgoda M, Zielińska E. Metoda audytywno-werbalna w rehabilitacji słuchu i mowy dzieci z wadą słuchu, zasady i praktyka. Nowa Audiofonologia, 2013; 2(4): 22-27.

23. Szuchnik J. Poprzez słuchanie do słowa. Warszawa: Stowarzyszenie Przyjaciół Osób Niesłyszących i Niedosłyszących „Człowiek - Człowiekowi”; 2000.

24. Skarżyński H, Szuchnik J, Mueller-Malesińska M. Implanty ślimakowe - rehabilitacja. Warszawa: Stowarzyszenie Przyjaciół Osób Niesłyszących i Niedosłyszacych „Człowiek - Człowiekowi”; 2004.

25. Zgoda M, Lorens A, Obrycka A, Putkiewicz-Aleksandrowicz J, Skarżyński H. Analiza porównawcza osiągnięć szkolnych trzynastolatków korzystających z implantu ślimakowego wszczepionego im przed ukończeniem 3 roku życia i słyszących rówieśników. Nowa Audiofonologia, 2014; 3(5): 66-74.

26. Purch R, Hyde MB. Communication, psychosocial, and educational outcomes of children with cochlear implants and challenges remaining for professionals and parents. Int J Otolaryngol, 2011; 2011: 573280.

27. Mukari SZ, Lai NL, Hanizam AG. Educational performance of pediatric cochlear implant recipients in mainstream classes. Int J Pediatr Otorhinolaryngol, 2007; 71(2): 231-40.

28. Rostkowska J, Wojewódzka B, Kobosko J i wsp. Możliwości słuchowe dorosłych osób ogłuchłych zaopatrzonych w implant ślimakowy. Nowa Audiofonologia, 2012; 1: 46-49.

29. Szuchnik J i wsp. Tłumaczenie i opracowanie w polskiej wersji językowej materiału słownego stosowanego w programie rehabilitacji słuchu dorosłych pacjentów implantowanych z postlingwalnym ubytkiem słuchu na podstawie materiałów firmy MED-EL oraz COCHLEAR. Materiał niepublikowany. Warszawa: Ośrodek Diagnostyczno-Leczniczo-Rehabilitacyjny „Cochlear Center"; 1993/1994.

30. Pankowska A, Rostkowska J. Materiał językowy wykorzystywany w rehabilitacji słuchu pacjentów z głuchotą postlingwalną. Nowa Audiofonologia, 2015; 4(2): 75-80.

31. Kelsall DC, Shalop JK. Cochlear implantation in the elderly. AM J Otol, 1995; 16: 609-15.

32. Lenarz M, Sönmez H, Joseph G, Büchner A, Lenarz T. Cochlear implant performance in geriatric patients. Laryngoscope, 2012; 122: 1361-65.

33. Herzog 1, Schön F, Müller J, Knaus C, Scholtz L, Helms J. Long term results after cochlear implantation in elderly patients. Laryngorhinootologie, 2003; 82: 490-93.

34. Filipo R, Ballantyne D, D'Elia C i wsp. Cochlear implantation in elderly: Indication and results. BMC Geriatrics, 2010; 10 (Supl 1): 107.

35. Chatelin V, Kim EJ, Driscoll C, Larky J, Polite C, Price L i wsp. Cochlear implant outcomes in the elderly. Otol Neurotol, 2004; 25: 298-301.

36. Vermeire K, Brokx JP, Wuyts FL, Cochet E, Hofkens A, Van de Heyning PH Quality-of-life benefit from cochlear implantation in the elderly. Otol Neurotol, 2005; 26: 188-95.

37. Shin YJ, Fraysse B, Deguine O, Valès O, Laborde ML, Bouccara D i wsp. Benefits of cochlear implantation in elderly patients. Otolaryngol Head Neck, 2000; 122: 602-6.

38. Pasanisi E, Bacciu A, Vincenti V, Guida M, Barbot A, Berghenti MT i wsp. Speech recognition in elderly cochlear implant recipients. Clin Otolaryngol Allied Sci, 2003; 28: 154-57. 
39. Waltzman SB, Cohen NL, Shapiro WH. The benefits of cochlear implantation in the geriatric population. Otolaryngol Head Neck Surg, 1993; 108: 329-33.

40. Steuden S. Psychologia starzenia się i starości. Warszawa: PWN; 2012
41. Silver Team, czyli potęga doświadczenia. Projekt współfinansowany przez UE w ramach Europejskiego Funduszu Społecznego. Nr projektu: WND-POLK. 06.01.01-02-209/10. www.silverteam.dobrekadry.pl. 